\title{
BIFUNGITES CF HALLI FROM THE ORDOVICIAN (CARADOCIAN) TRENTON LIMESTONE OF THE QUEBEC CITY AREA
}

\author{
R.K. PICKERILL \\ Department of Geology, University of New Brunswick, Fredericton \\ New Brunswick, E3B 5A3 \\ W.B. FORBES \\ Department of Gellogy, University of Maine, Presque Isle \\ Maine 04769
}

\section{INTRODUCTION}

Bifungites was an ichnogenus established by Desio in 1940 for certain dumb-bell shaped trace fossils found in Late Devonian rocks in Libya. Since its original diagnosis it has been reported in rocks ranging in age from (?) Cambrian to Upper Devonian (Dubois and Lessertisseur 1964, Häntzschel 1975) and is particularly conspicuous in Devonian strata, where it has been reported and, or, described by Gutschick et al 1962, Dubois and Lessertisseur 1964, Rodriguez and Gutschick 1970, Gutschick and Lamborn 1975, and Melou and Plusquellec 1975. Indeed, some of its supposed pre-Devonian occurrences are questionable as many of the original specimens described for example by Hall (1852) and Zenger (1971) from the Silurian Clinton Group of New York have been destroyed, can no longer be located or are not illustrated. Furthermore, detailed descriptions of the trace fossils were incomplete and the traces could easily have been synonymous with the morphologically similar ichnogenera Arthraria, Corophioides or Diplocraterion. One of the purposes of this paper is, therefore, to record in some detail a definitive Ordovician occurrence of Bifungites.

In ichnology it is extremely rare when the producer of a trace can be identified with confidence as unrelated groups are sometimes morphologically very similar and can therefore produce similar traces, or groups are morphologically very differen' bu behave $i$ a similar $m$ er due ' $p^{\prime} y s i$. and biological parameters and again produce similar traces (Osgood 1970). This is particularly true when the producer of a particular trace is a softbodied organism as the preservation potential for such organisms is extremely low. In spite of these inherent difficulties an assessment of the zoological affinities of the Bifungites trace is also attempted in this paper and comment is made on its palaeoecology.

\section{LOCATION AND GEOLOGIC BACKGROUND}

The Middle Ordovician (Caradocian) Trenton limestone northeast of the quebec City area consists of a number of small autochthonous outliers that sit with pronounced unconformity on an undulating surface of Precambrian Grenville Gneiss (Riva 1972). The rocks are abundantly fossiliferous and consist of a combined thickness of at least $160 \mathrm{~m}$ of Trenton limestone (Raymond 1912) with a few centimetres to as many as $33 \mathrm{~m}$ of basal sandstone (Riva 1972). Lithologically the limestones are composed of fossiliferous calcarenites and calcisiltites, biosparites and biomicrites with thin shale and calcareous shale interbeds. They represent a Middle Ordovician transgressive platformal sequence which is extremely MARITIME SEDIMENTS Vol. 13, No. 3, December 1977 pp. 87-92. shallow-water in origin near its base then progressively deepens to subtidal shallow shelf and deeper water shelf towards the top of the sequence until finally it is overlain by the greywacke flysh succession of the Utica shales (Riva et al 1977). In addition to being a richly fossiliferous sequence the Trenton limestone here contains a moderately abundant and diverse ichnoassemblage consisting of Cruziana, Rusophycus, Bifungites, Diplocraterion, Planolites, Tomaculum, Chondrites, of. Chevronichnus, ef. Gyrochorte, of. Teichichnus and horizontal annelid-produced surface trails (Pickerill and Forbes, in press). The Bifungites trace fossils are located in a series of small quarries sited in one of the outliers in the Chateau Richer area some $22 \mathrm{~km}$ northeast of Quebec City (Fig. 1).

\section{DESCRIPTION}

\section{(i) Mode of Occurrence}

The Bifungites traces are found in convex hyporelief on lower surfaces of thinly bedded $(3-10 \mathrm{~cm})$ delicately laminated or occasionally cross-laminated extremely bioturbated fine grained calcisiltites. Arms associated with the dumb-bell shaped trace fossils (see below) extend upwards into these calcisiltites. Specimen outlines are usually welldefined and the dark colouration of the silt-filled burrows is in marked contrast to the lighter greybrown calcisiltites.

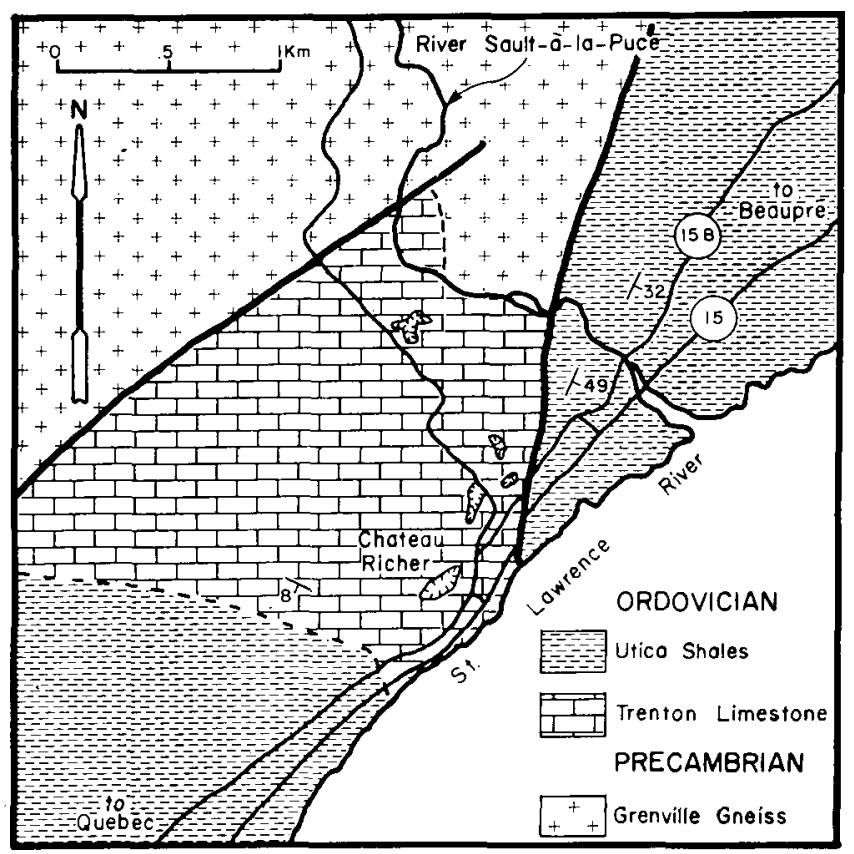

FIG. 1 Generalized geology and location map of the Chateau Richer area northeast of Quebec City. The map is based essentially on Riva (1972). 

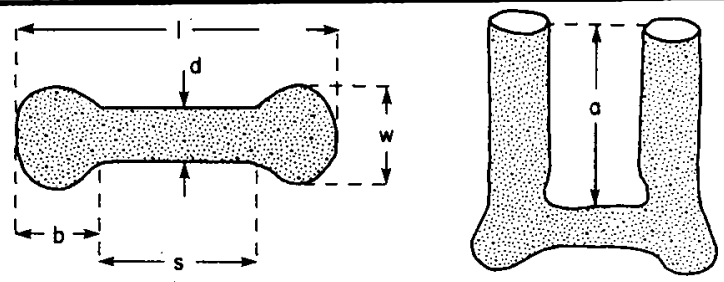

\begin{tabular}{lccccccc} 
& BASAL VIEW & & & \multicolumn{2}{c}{ SIDE } & VIEW \\
Maximum & $b$ & $d$ & 1 & $s$ & $w$ & $a$ \\
Minimum & 0.58 & 0.49 & 2.34 & 1.35 & 0.67 & 2.17 \\
Mean & 0.20 & 0.12 & 1.1 & 1 & 0.60 & 0.27 & 0.73 \\
Men & 0.38 & 0.29 & 1.83 & 1.04 & 0.46 & 1.34
\end{tabular}

FIG. 2 Diagrammatic representation of Bifungites illustrating its general morphology. The maximum, minimum and mean dimensions of the parameters $b$ (length of spherical dumb-bells), d width of basal chamber), $I$ (total length of the trace), s (length of the basal chamber excluding the spherical terminations), w (width of the dumb-bell terminations) and a (depth of the burrow) are also indicated. These parameters are those similarly utilized by Gutschick and Lamborn (1975) and Melou and Plusquellec (1975). 50 specimens were measured.

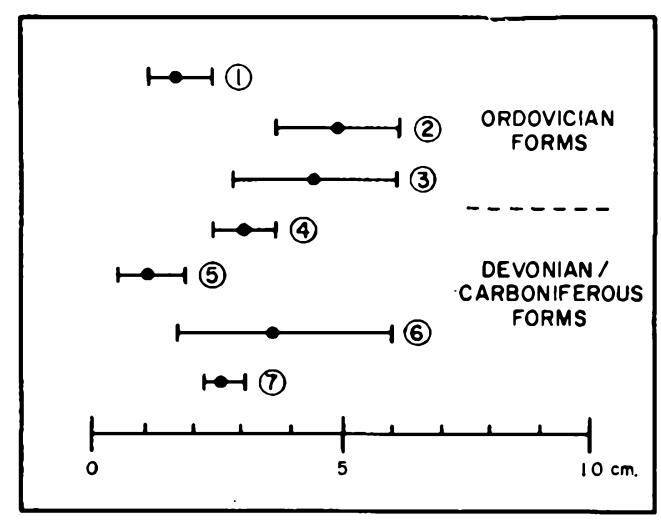

FIG. 3 Total length (1) of various forms of Bifungites. 1. is Bifungites cf. halli from the Trenton limestone. 2. is Bifungices sp. from Finistere, France, described by Melou and Plusquellec (1975). 3. is Bifungites sp. from the Ordovician of Bohemia also listed by Melou and Plusquellec (1975). 4. is Bifungites sp. from the Sahara. 5. is Bifungites bisagittula. 6. is Bifungites bieurysagitta. 7. is Bifungites bisagitta. 5-7 are described by Gutschick and Lamborn (1975). Specimens 1.3 are Ordovician (Caradoc) in age and 4-7 Devonian-Carboniferous.

(ii) Systematic Description

Ichnogenus Bifungites Desio 1940

Hall 1852, Pl. 10, Fig. 6; Desio, 1940, pp. 78-79, Pl. 8, Fig. 3; Gutschick et al. 1962, pp. 79-89, P1. 2, Figs. 13, 19-20; Häntzschel 1962, p. W186, Fig. 113.1; Dubois and Lessertisseur 1964, pp. 626634, 7 Figs, 1Pl; Osgood 1970, pp. 314-325, Figs. 7-8, P1. 60, figs. 3-4, Pl. 61, figs. 1-3, 7; Rodriguez and Gutschick 1970, pp. 418-419, Pl. 5, figs. a-f; Knox 1973, p. 172; Fürsich 1974, pp. 957, 959-960; Häntzschel 1975, p. W46, Fig. 21.1; Gutschick and Lamborn 1975, pp. 193-212, 10 Figs., 1Pl; Melou and Plusquellec 1975, pp. 465-479, 5 Figs.

Bifungites ef. halli Desio 1940

The trace consists of a U-shaped or, strictly speaking, an inverted pi-shaped burrow in which two vertical or subvertical cylindrical tubes extend upwards from a horizontal basal chamber. The horizontal basal chamber is cylindrical in cross-section and is typically smooth and unornamented though rare specimens do in fact exhibit closely spaced transverse annulations. (Fig. 4A). Typically the basal chamber width (d) is consistent

FIG. 4 Examples of Bifungites cf. halli from the Trenton limestone of the Quebec City area. A. Specimen illustrating transverse annulation across the basal cylindrical chamber preserved in convex hyporelief. B. Specimen illustrating basal chamber with its maximum width (d) located centrally, preserved in convex hyporelief. C. Polished section through B. cf. halli illustrating the typical inverted pi-shape of the burrow. Note the undisturbed sediment between the arms and the absence of spreiten. Bioturbation is particularly conspicuous in regions away from the burrow. $D$. B. cf. halli preserved in convex hyporelief with a simple trail entering and leaving the burrow. This indicated that the producing organism was vagile and not sessile as previously thought. E. Polished section of B. cf. halli illustrating well-developed basal chamber and vertical arms. The arms have undergone slight distortion probably as a result of compaction. Note the undisturbed sediment between the arms and the absence of spreiten. F. Typical dumb-bell shaped B. cf. halli with spherical terminations and a parallel sided basal chamber preserved in convex hyporelief. $G$. Polished section of $\mathrm{B}$. cf. halli illustrating poorly developed vertical arms. Note the undisturbed bedding between the tubes. $\mathrm{H}$ and $\mathrm{I}$. Two views of $\mathrm{B}$. cf. halli preserved in convex hyporelief illustrating the typical dumb-bell shape and the spherical lateral terminations. Note the typical colour contrast between the silt. filled burrows and the surrounding material. Bar scale in all cases is $1 \mathrm{sm}$, lithology is crinoidal bioturbated calcisiltite. 

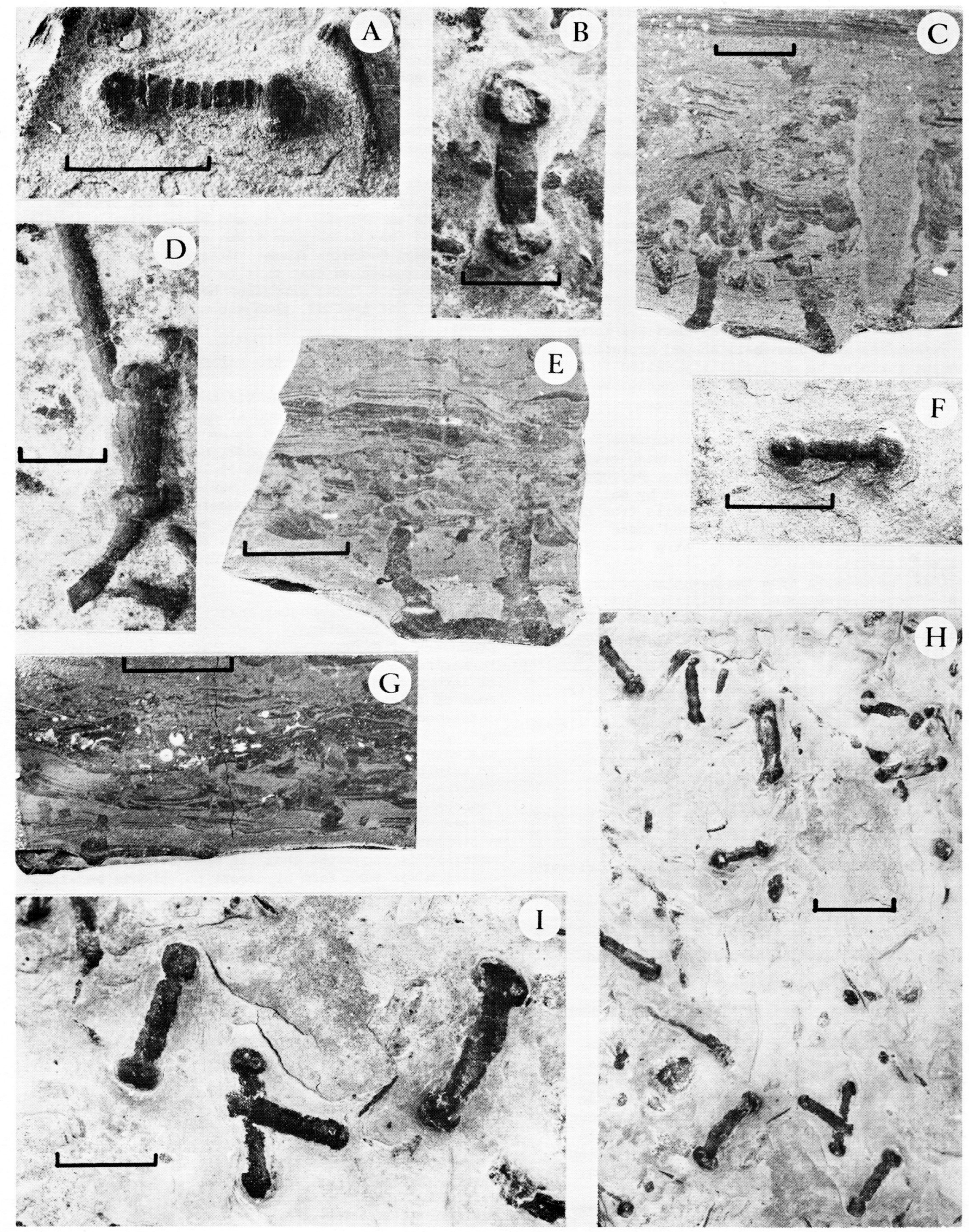
throughout its length, thus giving the basal chamber parallel sides. In occasional specimens, however, maximum width is located centrally within the chamber, which then decreases slightly in size towards both lateral terminations (Fig. 4B). The lateral terminations of the basal chamber are consistently spherical in shape and always project beyond the vertical tubes, thus giving the burrow the typical inverted pi-shape. The spherical terminations are consistently wider than the connecting basal chamber, thus giving the trace a characteristic dumb-bell appearance. Polished sections reveal that sediment between the vertical paired tubes is undisturbed and clearly lacks spreiten structures. Significant dimensions of the Trenton specimens are illustrated in Figure 2.

\section{(iii) Discussion}

When Desio (1940) originally defined the ichnogenus Bifungites as a dumb-bell shaped expression on bedding surfaces he unfortunately failed to mention any associated vertical tube structures. Desio distinguished two ichnospecies each based on the shape of the dumb-bell terminations. The Libyan representatives he referred to as Bifungites fezzanensis, these being characterized by hemispherical terminations. His second ichnospecies, Bifungites halli, was based on descriptions given by Hall (1852) of dumb-bell shaped trace fossils from the Silurian Clinton Group of New York and these possessed spherical terminations. At a later date Dubois and Lessertisseur (1964) also described Bifungites fezzanensis from the Devonian of the Sahara. Though no detailed descriptions were given they interpreted the traces as molds of Utube openings of spreiten-bearing Rhizocorallizm. The general absence of the complete and detailed descriptions subsequently led Osgood (1970) and later know (1973) to include species of Bifungites within the ichnogenus Corophioides, in particular Corophioides biclavatum. Later Fürsich (1974) placed Corophioides, and hence Bifungites, into synonymy with Diplocraterion, particularly Diptocraterion biclavatum. Diplocraterion spp. is indeed a Ushaped burrow morphologically very similar to Bifungites. However, Diplocraterion and its synonyms (Corophioides, Arthraria and Polyupsizon) are characterized by spreiten patterns between the Ushaped arms. As spreite are regarded as significant ichnogeneric features (Fürsich 1974) Bifungites cannot be regarded as a synonym of Dipiocraterion as spreite are always absent. The ichnogenus Bifungites must therefore remain a distinctive form ( $c f$. Gutschick and Lamborn 1975, Mélou and Plusquellec 1975).

Gutschick and Lamborn (1975) erected three new ichnospecies of Bifungites; $B$. bisagitta, $B$. bisagittula and $B$. bieurysagitta, from DevonianMississippian rocks of Pennsylvania and Montana. The three ichnospecies were separated on 'markedly different size and shape of the fossil traces in three stratigraphic zones' (Gutschick and Lamborn 1974, p. 193). However, examination of the size data indicates that there is considerable overlap between the three ichnospecies (Fig. 3) and, in addition, the ichnospecies each exhibit many gradations in burrow shape. Whether or not these three ichnospecies are meaningful and realistic is therefore open to question. specimens of Bifungites from the Trenton limestone exhibit little varjation in size or shape and are particularly charactelized by their spherical terminations. In this respect they closely resemble $B$. halli. Unfortunately no type specimens of $B$. halli are available in Hall's collections at the New York State Museum (Gutschick and Lamborn 1975, p. 194) and therefore the Trenton specimens are referred to as Bifungites cf. Bifunites halli.

At this point it is also worthwhile commenting on the size of Bifungites of. halli from the Trenton limestone as recently Mélou and Plusquellec (1975) concluded that Ordovician forms of Bifunites were bigger than Devonian forms. Clearly, the data in Figure 3 indicates that this is an oversimplication as the Trenton forms described here are equally as small, if not smaller, than the majority of Devonian forms.

\section{THE PRODUCER AND ITS PALAEOECOLOGY}

In general it is impossible to assign U-shaped burrows to any single group of organisms, as such burrows have been observed to be constructed by polychaete annelids, amphipods, echiuroids, hemichordates and freshwater insect larvae in modern marine and freshwater environments (Osgood 1970, Häntzschel 1975). With the possible exception of the hemichordate Balanoglossus, however, the majority of these organisms are sedentary filterfeeders, which feed by setting up currents with the aid of moving parapodia or equivalent mechanisms and drawing in organic detritus. The exception is the case of the freshwater insect larvae which can obviously be immediately dismissed as possible producers of Bifungites as the latter is restricted to marine sediments. Bifungites can therefore be interpreted as a trace fossil produced by some form of filter-feeder(s). When Desio (1940) first described Bifungites he interpreted it as a 'fucoid' or 'colonial animal'. Subsequent examination of his material led Dubois and Lessextisseur (1964) to interpret the burrows as dwelling structures (domichnia) of small trilobites. Gutschick and Lamborn (1975) interpreted the burrows as domichnia of sedentary soft-bodied infaunal filter-feeders. A similar interpretation is adopted here and, furthermore, it is suggested that the most likely producing organism was some form of errant polychaete annelid. This conclusion is based on the following:

1. Though a variety of organisms have been suggested to possess the ability of constructing Ushaped burrows (see above) the majority of such burrows, for example Arenicolites, Arthraria, Corophioides, and Diplocraterion are usually attributed to polychaete annelids (Osgood 1970, Häntzschel 1975, Hakes, 1976) and only rarely to amphipods, echiuroids or hemichordates.

2. Rare specimens of Bifungites of. halli (Fig. 4A) actually preserve detail of transverse segmentation or annuli, this segmentation presumeably reflecting the detailed anatomy of the producer. This inmediately dismisses echiuroids as potential producers, as the phylum echiurida are unsegmented, thus suggesting that the potential producers were amphipods, hemichordates or annelids. 
3. Amphipods are malacostracean crustaceans and as such are distinctly segmented. However, it is generally accepted that arthropod (crustacean) burrows are particularly characterized by spreite and scratch markings (Osgood 1970). Indeed, other crustacean-produced ichnogenera (e.g. Thalassinoides, Isopodichnus, Spongeliomorpha, ophiomorpha, etc.) are all characterized by scratch markings preserved particularly on the walls of the burrows. The obvious absence of both spreite and scratch markings therefore suggests that amphipods did not produce Bifungites.

4. If the potential producer of Bifungites was a hemichordate then only the vermiform class enteropneusta would be capable of producing such burrows as other classes live in aggregates or colonies enclosed within a secreted encasement. Some enteropneusts, such as Balanoglossus and Saccoglossus, do in fact live in U-shaped burrows but the majority of genera, such as Ptychodera, Spengelia, and Glandiceps do not make definitive burrows but live buried immediately below the sediment-water interface. Balanoglossus and Saccoglossus live in sand substrates with burrows usually in the order of 10 to $30 \mathrm{~cm}$ in diameter (Hyman 1959). Thus the observed substrate type and burrow diameter contrasts strongly with those observed for Bifungites. In addition, enteropneust hemichordates are sluggish and inactive animals, rarely, if ever, venturing from their burrows and never crawling on or below the surface (Hyman $1959 \mathrm{p}$. 141). In the Trenton limestone, specimens have been observed (Fig. 4D) where trails enter and leave the typical Bifungites trace. Detailed slabbing indicates that these trails were obviously constructed by the Bifungitesproducer. Thus it is apparent that the producer was in fact vagile and utilized the U-shaped burrows merely for feeding purposes. The evidence suggests that hemichordates were therefore not responsible for producing the burrows.

5. The most commonly associated trace fossils with Bifungites are simple, straight to meandrine crawling trails. These trails are identical in width to the Bifungites traces suggesting that similar sized organisms produced both types of trace and, furthermore, as stated above, rare specimens demonstrate that the producer responsible for the trails was also probably responsible for Bifungites. It was recently demonstrated by Pickerill and Forbes (in press) that morphologically similar trails were produced by earrant polychaete annelids, as a single example of one of these trails actually preserved its producing annelid Walcottia mugosa. Thus there is good evidence to suggest that Bifungites was produced by errant polychaete annelids.

Based on these observations it therefore appears that the organism responsible for the Bifungites trace was in all probability an errant polychaete annelid. The annelid lived in the uppermost few centimetres in silt substrates and employed its constructed Bifungites trace as a means of protection from predation and as an aid in filterfeeding. In terms of palaeoenvironment, the infaunal annelids most probably lived in 'shallow' areas where current energy and sedimentation rates were low but where there was an adequate supply of oxygen and food for the benthos. Low sedimentation rates are indicated by extensive associated bioturbation and low current energy by the absence of erosive structures and the general absence of bedforms such as ripples and cross-bedding. Associated ichnofaunas with Bifungites and the simple trails described previously include Cruziana, Rusophycus, Planolites, ef. Chevronichnus and of. Gyrochorte, a Cmuziana-ichnofacies assemblage (Seilacher 1964) indicative of 'shallow' marine conditions. Associated biota includes a variety of linguloid, orbiculoid, dalmanellid, orthid and strophomenid brachiopods; trinucleid, calymenid and encrinurid trilobites and crinoids, an assemblage similarly indicative of 'shallow' marine conditions. Thus it appears likely that the producing infaunal polychaete annelids lived in 'shallow' marine conditions, which is in agreement with Gutschick and Lamborn (1975), who recently suggested that Bifungites are most likely to be found in tidal flat environments, delta and bar margins and very shallow basinal areas. Unfortunately specific details of sub-environments or related physical environmental parameters such as temperature, salinity and water depth must remain obscure as there is no positive evidence with which to assess them.

\section{CONCLUSIONS}

This study of Bifungites of. halli from the Trenton limestone of the Quebec City area has indicated that:

1. Bifungites as a distinctive ichnogenus must be retained and must not be placed into synonymy with the related ichnogenera Arthraria, Corophioides and Diplocraterion; as suggested by Knox (1973) and Fürsich (1974).

2. Ordovician forms of Bifungites are not necessarily bigger than Devonian forms, as suggested by Mélou and Plusquellec (1975).

3. The most Iikely producer of Bifungites was some unknown errant polychaete annelid which utilized the burrows as domichnia and adopted a filter-feeding mode of life.

4. The organism responsible for the burrows was probably also responsible for the trails commonly found in association with Bifungites. Thus the polychaete annelid did not adopt a strictly sedentary mode of life as recently suggested by Gutschick and Lamborn (1975).

5. The Bifungites organism inhabited 'shallow' marine environments, though the exact nature of these environments in terms of water depth and other physical environmental parameters, such as temperature and salinity, are indeterminate.

\section{ACKNOWLEDGEMENTS}

We wish to thank Bob McCulloch who prepared the figures, Dave Nickson for his technical assistance and Sherri Townsend who prepared the manuscript. Collection of the many specimens on which this paper is based was assisted by U.M.P.I. students, whose aid is gratefully acknowledged. 


\section{REFERENCES}

DESIO, A. 1940-XVIII. Vestigia problematiche Paleozoiche della Libia. Mus. Libico Stor. Nat., Ann., 2 pp. 47-92.

DUBOIS, P. and LESSERTISSEUR, J. 1964. Note sur Bifungites, trace problêmatique du Devonian du Sahara. Bull. Soc. Geol. Fr. 7, pp. 626-634.

FüRSICH, F.T. 1974. On Diplocraterion Torell 1870 and the significance of morphological features in vertical spreiten-bearing, U-shaped trace fossils. J. Paleontol. 48, pp. 952-962.

GUTSCHICK, R.C. and LAMBORN, R. 1975. Bifungites, trace fossils from Devonian-Mississippian rocks of Pennsylvania and Montana, U.S.A. Palaeogeogr., Palaeoclimatol., Palaeoecol. 18, pp. 193-212.

GUTSCHICK, R.C., SUTTNER, L.J. and SWITEK, M.J. 1962. Biostratigraphy of transitional DevonianMississippian Sappington Formation of southwest Montana. In: Billings Geol. Soc. Guidebrook, 23th Ann. Field Conf., pp. 79-89.

HAKES, W.G. 1976. Trace fossils and depositional environment of four clastic units, Upper Pennsylvanian megacyclothems, northeast Kansas. Univ. Kansas, Faleontol. Contrib. Article $63,46 \mathrm{pp}$.

HALL, J. 1852. Nat. Hist. New York, Paleontology, New York, Albany 2, $362 \mathrm{pp}$.

HÄNTZSCHEL, W. 1962. Trace fossils and problematica. In: (R.C. Moore, ed.), Treatise on Invertebrate Paleontology, Part W, Miscellanea. Geol. Soc. $\mathrm{Am}$. and University of Kansas Press, pp. 171-245.

1975. Trace fossils and problematica. In: (R.C. Moore, ed.), Treatise on Invertebrate Paleontology, Part W, Miscellanea. Geol. Soc. $\mathrm{Am}$. and University of Kansas Press, $269 \mathrm{pp}$.

HYMAN, L.H. 1959. The Invertebrates. Smazler Coelomate Groups. McGraw-Hill Book Co. 783 pp.
KNOX, R.W.O'B 1973. Ichnogenus Corophioides. Lethaia 6, pp. 133-146.

MELOU, M. and PLUSQUELLEC, ฬ. 1975. Sur Bifungites? (Problematica) du "Grès de Kermerie", Ordovicien de la Presqu'île de Crozon (Finistere, France). Neues Jarb. fuer Geol. und Palaeont., Monats. 8, pp. 465-479.

OSGOOD, R.G. 1970. Trace fossils of the Cincinnati area. Paleontograph. Amer.6, pp. 281-444.

PICKERILL, R.K. and FORBES, W. (in press). A trace fossil preserving its producer (Walcottia mugosa) from the Trenton limestone of the Quebec City area. Can. J. Earth Sci.

RAYMOND, P.E. 1912. The Trenton Group in Ontario and Quebec. Geol. Sum. Canada Summ. Report, pp. 342-350.

RIVA, J. 1972. Geology of the environs of Quebec City. Excursion 19, Int. Geol. Congress. Canada, 53 pp.

RIVA, J., BELT, E.S. and MEHRTENS, C.J. 1977. The Trenton, Utica and Flysch succession of the Platform near Quebec City, Canada. In: (Béland, R. and LeSalle, P., eds.), N.E.I.G.C. guidebook of excursions in the province of Quebec, pp. A8-1-37.

RODRIGUEZ, J. and GUTSCHICK, R.C. 1970. Late Devonian-Early Mississippian ichnofossils from western Montana and northern Utah. In: (Crimes, T.P. and Harper, J.C., eds.). Trace Fossils. Geol. J. Spec. Issue 3, pp. 407-438.

SEILACHER, A. 1964. Biogenic sedimentary structures. In: (Imbrie, J. and Newell, N.D., eds.). Approaches to Paleoecology. John Wiley and Sons Inc. pp. 296-316.

ZENGER, D.H. 1971. Uppermost Clinton (Middle Silurian) stratigraphy and petrology east-central New York. N.Y. State Mus. Sci. Serv. Bulz. 417, 58 pp. 